\title{
Evaluation of female fertility in dairy cattle enterprises - A review
}

\author{
R.D. Kgari ${ }^{1,2 \#}$, C.J.C. Muller ${ }^{2}$, K. Dzama ${ }^{2} \&$ M.L. Makgahlela ${ }^{1,3}$ \\ ${ }^{1}$ Agricultural Research Council, Private Bag X2, Irene 0062, South Africa \\ ${ }^{2}$ Department of Animal Sciences, University of Stellenbosch, Stellenbosch 7600 , South Africa \\ ${ }^{3}$ University of the Free State, Department of Animal, Wildlife and Grassland Sciences, PO Box 339 Bloemfontein 9301, \\ South Africa
}

(Submitted 16 September 2020; Accepted 3 September 2020; Published 7 December 2020)

\begin{abstract}
Copyright resides with the authors in terms of the Creative Commons Attribution 4.0 South African Licence.
See: http://creativecommons.org/licenses/by/4.0/za

Condition of use: The user may copy, distribute, transmit and adapt the work, but must recognise the authors and the South African Journal of Animal Science.
\end{abstract}

\begin{abstract}
The aim of this article was to review the state of fertility of female dairy cattle in South Africa and to compare it with international efforts at improving fertility. Fertility in dairy cows is defined as the ability to conceive from first insemination soon after calving and to carry the calf full term to calving. It is one of the main profit drivers in the dairy industry and is a complex trait that is influenced by the environment, genetics, and their interaction. Generally, there has been a decline in dairy cow fertility across breeds worldwide because of intense selection for milk yield, milk components, and body conformation traits. In addition, most fertility traits are negatively correlated to milk production traits. Milk production has been the focal point of selection programmes as it is linked directly to the profitability of the dairy enterprise. The low heritability of fertility traits is one of the factors that discouraged efforts to include fertility in genetic evaluations. However, owing to its economic importance, female fertility was later included in the breeding objectives for dairy cattle in several countries. Although most fertility traits are heritable to a low degree, some additive genetic variability can be exploited.
\end{abstract}

Keywords: breeding values, cow fitness, genetic improvement, heritability

\#Corresponding author: kgarir@arc.agric.za

\section{Introduction}

Female fertility is a complex multi-factorial trait that includes the animal's genetic composition (Miglior, 1999) and environmental conditions such as nutrition and climate (Muller et al., 2014), the endocrine system (Potgieter, 2012), the age of the animal and on-farm management practices. In enhancing fertility through advanced reproductive biotechnologies, a clear understanding of the hormonal mechanisms that control the oestrus cycle is required for inseminators to detect oestrus signs accurately to increase pregnancy rates.

The breeding goal of most dairy farmers is to increase the profitability of their enterprise. This should be achieved without any detriment to animal health and welfare and the environment. The milk yield of cows determines the profitability of a dairy enterprise. However, there are several other profit drivers, for example longevity, disease resistance, feed efficiency and fertility. These traits should be incorporated into the dairy breeding plan and each should play a role in determining the profitability of dairy herds by decreasing input costs of production. These expenses include repeated artificial insemination (Al) services, extra hormonal treatments, veterinary examinations and treatments of cows that are susceptible to disease, and outsourcing of replacement heifers. Major economic losses are also incurred through culling as a result of reproductive problems and reduced incomes because of long calving intervals (Seegers, 2006). In a poor reproductive performance scenario, an average net economic loss of €231 per cow per year was observed in The Netherlands (Inchaisri et al., 2010).

Breeding programmes have focused on selecting for increased milk production (Evans et al., 1999; Pryce \& Veerkamp, 2001). However, fertility in dairy cows has decreased strongly over the last decades as milk production per cow increased significantly (Dillon et al., 2006; Makgahlela et al., 2007; Cassandro, 2014), because of the antagonistic relationship between fertility and milk production that is associated with pleiotropic effects of alleles for production and fertility (Glaze, 2011). Conventional breeding programmes have neglected fertility for several reasons including that it does not produce a saleable commodity. 
Generally, fertility traits have low heritabilities (Table 1), indicating that they are heavily influenced by the environment. However, there is sufficient additive genetic variation to warrant their genetic improvement through selection (Miglior et al., 2005; Makgahlela et al., 2007; Banga et al., 2009; Muller et al., 2014).

Table 1 Heritability $\left(h^{2}\right)$ estimates and standard errors (SE) of fertility traits observed in various breeds worldwide

\begin{tabular}{|c|c|c|c|c|}
\hline Fertility trait & Breed & $h^{2} \pm \mathrm{SE}$ & Country & Reference \\
\hline \multirow{4}{*}{$\begin{array}{l}\text { Calving } \\
\text { Interval }\end{array}$} & Holstein-Friesian & $0.07 \pm 0.00$ & Italy & Biffani et al., 2003 \\
\hline & Holstein & $0.03 \pm 0.01$ & South Africa & Makgahlela et al., 2007 \\
\hline & Simmental & $0.02 \pm 0.07$ & Turkey & Ulutas \& Sezer, 2009 \\
\hline & Fogera Holstein-Friesian & $0.05 \pm 0.09$ & Ethiopia & Zeleke et al., 2016 \\
\hline \multirow{5}{*}{$\begin{array}{l}\text { Age at first } \\
\text { Calving }\end{array}$} & Multiple breeds & $0.13 \pm 0.01$ & New Zealand & Grosshans et al.,1997 \\
\hline & Ayrshire & $0.09 \pm 0.05$ & Kenya & Amimo et al., 2006 \\
\hline & Holstein & $0.24 \pm 0.02$ & South Africa & Makgahlela et al., 2007 \\
\hline & Fogera Holstein-Friesian & $0.15 \pm 0.23$ & Ethiopia & Zeleke et al., 2016 \\
\hline & Girolando & $0.27 \pm 0.03$ & Brazil & Canaza-Cayo et al., 2017 \\
\hline \multirow{5}{*}{$\begin{array}{l}\text { Days } \\
\text { Open }\end{array}$} & Multiple breeds & $0.02 \pm 0.00$ & Brazil & Grosshans et al., 1997 \\
\hline & Holstein & $0.05 \pm 0.02$ & China & Guo et al., 2014 \\
\hline & Holstein & $0.03 \pm 0.00$ & Tunisia & Zaabza et al., 2016 \\
\hline & Holstein & $0.02 \pm 0.01$ & Iran & Rahbar et al., 2016 \\
\hline & Fogera Holstein-Friesian & $0.01 \pm 0.05$ & Ethiopia & Zeleke et al., 2016 \\
\hline \multirow{5}{*}{$\begin{array}{l}\text { Services per } \\
\text { conception }\end{array}$} & Multiple breeds & $0.01 \pm 0.01$ & New Zealand & Grosshans et al.,1997 \\
\hline & Swedish Red and White & $0.02 \pm 0.16$ & Sweden & Roxstroem et al., 2001 \\
\hline & Holstein & $0.10 \pm 0.02$ & South Africa & Potgieter, 2012 \\
\hline & Holstein & $0.01 \pm 0.01$ & Iran & Eghbalsaied, 2011 \\
\hline & Holstein & $0.04 \pm 0.03$ & Iran & Rahbar et al., 2016 \\
\hline \multirow{5}{*}{$\begin{array}{l}\text { Calving to } \\
\text { first service }\end{array}$} & Multiple breeds & $0.03 \pm 0.00$ & Brazil & Grosshans et al.,1997 \\
\hline & Holstein & $0.14 \pm 0.02$ & Iran & Eghbalsaied, 2011 \\
\hline & Holstein & $0.04 \pm 0.01$ & Czech Rep & Zink et al., 2012 \\
\hline & Holstein & $0.04 \pm 0.01$ & Iran & Toghiani, 2012 \\
\hline & Holstein-Friesian & $0.07 \pm 0.00$ & Ireland & Berry et al., 2013 \\
\hline \multirow{4}{*}{$\begin{array}{l}\text { Non return } \\
\text { rate } 56 \mathrm{~d}\end{array}$} & Holstein-Friesian & $0.02 \pm 0.00$ & Italy & Biffani et al., 2003 \\
\hline & Holstein-Friesian & $0.01 \pm 0.00$ & Netherlands & De Haer et al., 2013 \\
\hline & Holstein & $0.01 \pm 0.00$ & China & Liu et al., 2017 \\
\hline & Holstein-Friesian & $0.03 \pm 0.01$ & Germany & Yin \& König, 2018 \\
\hline
\end{tabular}

Denmark, Sweden, and Finland were the first to include health and fertility traits in selection programmes in the mid 1990s, whereas countries such as New Zealand followed in 1998 and the USA in 2001 (Wesseldijk, 2004). The inclusion of fertility traits in South African selection programmes was recommended only in 2007 (Makgahlela et al., 2007). To date, the genetic evaluation for fertility in South Africa is based on traits derived from calving dates (that is, age at first calving (AFC) and calving interval $(\mathrm{Cl})$ ). But these traits become available late in an animal's life and can easily be influenced by management or breeder.

Calving interval and AFC are the result of actions that could be used as fertility indicators. The inclusion of fertility in dairy cattle selection programmes is based on its economic value to the herd. Advances in genomic technologies promise a leap forward in the genetic improvement of difficult to measure traits such as fertility. For example, genomic selection exploits genome-wide dense single nucleotide 
polymorphism (SNP) markers to predict breeding values for breeding stock (Meuwissen et al., 2001). The accuracy of genomic predictions in low heritable traits exceeds that of parental averages for young animals without phenotypes of their own, which would accelerate the rate of genetic improvement for low heritable traits (Viana et al., 2016).

South Africa was among developing countries that lagged behind developed countries in the inclusion of fertility traits in selection programmes (Wesseldijk, 2004). This article reviews the state of female dairy cattle fertility in South Africa, and comparisons are made with international efforts at genetic improvement of this complex trait. This study indicates progress after the inclusion of fertility in South African selection indexes.

The profitability of dairy cattle depends not only on milk production, but also on non-production characteristics such as fertility and health traits (Toghiani, 2012). These are important in minimising cost and maximizing the net return of the dairy enterprise (that is, they increase biological and economic efficiency). Sound reproductive management can have tremendous positive effects on profitability, and one of the key components of modern dairy production is the analysis of reproductive records. Accurate and reliable onfarm records can help guide producers, veterinarians and consultants to make better decisions about reproductive management (Overton, 2009).

Poor reproductive performance affects profitability greatly in a dairy herd as it is one of the reasons for involuntary culling, for example 25\% in France (Colleau \& Moureaux, 1999), 21\% in Iran (Ghaderi-Zefrehei et al., 2017) and 18.5\% in South Africa (Anonymous, 2017). Involuntary culling also has a negative impact on dairy economics because rearing or purchasing a replacement heifer is far more expensive than the salvage value of culled cows (Lavern, 2017). Economic losses can also be owing to a loss of production because of prolonged Cls (Van Arendonk et al., 1989; Olori et al., 2002). Banga et al. (2009) showed that an increase in $\mathrm{Cl}$ caused a decrease in profit, which agrees with several other studies (Visscher et al., 1994; Du Plessis \& Roux, 1998; Holmes et al., 2000; Olori et al., 2002; Veerkamp et al., 2002). This highlights the need to include most traits of economic importance in breeding objectives and selection indices with accurately weighted economic values. Little research has been done in South Africa on the economics of dairy cow fertility. A study by Cervo et al. (2017) reported a decrease in profit margins for age at first calving (-1 to -25$)$ and $\mathrm{Cl}(-0.4$ to -24$)$, indicating that producers need to select for early calving animals and shorter Cls to increase profit margins. Inclusion of these non-yield traits in selection indices is important for the dairy producer's profits, even though there is wide variation among countries in traits that are included in selection indexes and in relative economic weights (Shook, 2006).

Female fertility is influenced largely by the environment, but genetics also plays a significant role in the reproductive performance of dairy herds. Cows selected for high milk yields have shown declines in fertility (Walsh et al., 2011) because of the pleiotropic effect of genes for production and fertility in which similar genes underlie expression of these traits, but in reverse modes (Glaze, 2011). Efforts to select for improved fertility were in part discouraged by the low heritabilities exhibited by fertility traits. Thus, breeders thought that fertility could then be improved through better management systems. However, studies showed that there is sufficient additive genetic variation among fertility traits to warrant their improvement through selection (De Jong, 1998; Weigel \& Rekaya, 2000; Norman et al., 2009; De Haer et al., 2013).

In the 1990s, some Scandinavian countries included fertility in their selection indices by using multitrait selection (Leitch, 1994). Functional traits are currently included in selection indices of various countries (Table 2). Although the South African index previously included only production (63\%) and type (37\%) traits (Wesseldijk, 2004), the breeding objectives for dairy cattle were revised to include a small proportion of selection for milk production traits because a turnaround has been made in selection goals for dairy cattle bulls by emphasising body conformation traits (e.g. udder, feet and legs, and size), health traits (somatic cell counts indicating mastitis), fertility and longevity (Theron \& Mostert, 2019). The percentages or weights of the traits in the indices change as production and market prices change and new estimated breeding values (EBV) for the traits become available.

Interval traits are most commonly used for fertility evaluation, in part because they are simple to measure and record, and are available on a large scale (Table 3). Often the only count trait that is used is services per conception (Potgieter, 2012), which is seldom explored because it requires insemination and pregnancy records, which are not routinely recorded in South Africa (Mostert et al., 2010). Lack of sufficient data therefore makes it difficult to evaluate fertility broadly. Hence genetic evaluations for fertility are based only on Cl and AFC (Makgahlela et al., 2007; Banga et al., 2009; Potgieter et al., 2011). Although the genetic evaluation of $\mathrm{Cl}$ ensures that fertility is included in breeding objectives, which is a good step towards the improvement of fertility in dairy cows, it has its limitations because of the lack of animal information until the second parturition. It results in biased management decisions and inaccurate prediction of breeding values because the evaluations are based only on cows that calved at least twice, excluding heifers and cows that are perceived to be least fertile and those culled for not becoming pregnant (Esslemont,1992; Haile-Mariam 
et al., 2003; Muller et al., 2012). The use of $\mathrm{Cl}$ and AFC as the main fertility traits represents a setback because the estimated breeding value (EBV) for $\mathrm{Cl}$ become available to the industry at least a year later than those of production traits, whereas AFC is open to management bias.

Table 2 Various selection indices and their corresponding relative economic weight for each trait

\begin{tabular}{|c|c|c|c|c|}
\hline Index & Country & Trait & $\%$ & Reference \\
\hline \multirow{3}{*}{$\begin{array}{l}\text { Nordic total merit index } \\
\text { (NTM) }\end{array}$} & \multirow{3}{*}{$\begin{array}{l}\text { Denmark } \\
\text { Finland } \\
\text { Sweden }\end{array}$} & Health and fertility & 53 & \multirow{3}{*}{ NTM unlocked, 2017} \\
\hline & & Production & 30 & \\
\hline & & Functional conformation & 17 & \\
\hline \multirow{5}{*}{ Total merit index (TMI) } & \multirow{5}{*}{ Germany } & Production & 50 & \multirow{5}{*}{ Rensing et al., 2002} \\
\hline & & Longevity & 25 & \\
\hline & & Conformation & 15 & \\
\hline & & Udder health & 5 & \\
\hline & & Reproduction & 5 & \\
\hline \multirow{3}{*}{$\begin{array}{l}\text { Total performance } \\
\text { index (TPI) }\end{array}$} & \multirow{3}{*}{ USA } & Production & 43 & \multirow{3}{*}{ Meyer \& Zwald, 2014} \\
\hline & & Health & 28 & \\
\hline & & Conformation & 29 & \\
\hline
\end{tabular}

Table 3 Measures of reproductive performance that can be derived from artificial insemination events recorded from on-farm automated systems.

\begin{tabular}{|c|c|c|}
\hline Trait & Trait category & Description of the trait \\
\hline Age at first service & Interval & $\begin{array}{l}\text { Age at which a heifer was first } \\
\text { inseminated (months) }\end{array}$ \\
\hline Age at first calving & Interval & $\begin{array}{l}\text { Age at which a heifer gives birth to its } \\
\text { first calve (months) }\end{array}$ \\
\hline Days Open & Interval & $\begin{array}{l}\text { Number of days from calving to } \\
\text { conception }\end{array}$ \\
\hline Calving to first service & Interval & $\begin{array}{l}\text { Number of days from calving date to the } \\
\text { date of the next first service }\end{array}$ \\
\hline First service $<80$ days & Success & $\begin{array}{l}\text { If a cow was inseminated within } 80 \\
\text { days post partum }\end{array}$ \\
\hline Services per conception & Count & $\begin{array}{l}\text { Number of services required for a cow } \\
\text { to conceive }\end{array}$ \\
\hline Pregnant $<100$ days & Success & $\begin{array}{l}\text { If a cow was confirmed pregnant within } \\
100 \text { days post partum }\end{array}$ \\
\hline Pregnant $<200$ days & Success & $\begin{array}{l}\text { If a cow was confirmed pregnant within } \\
200 \text { days post partum }\end{array}$ \\
\hline
\end{tabular}

Potgieter et al. (2011) and Muller et al. (2012) explored the possibility of using farmers' service records to derive additional measures of fertility using small datasets. They concluded that there is sufficient scope for selection of fertility because traits such as calving to first service, services per conception, and days open could be used to predict the ability of the cows to conceive. Countries such as Ethiopia and The Netherlands have explored the use of reproductive performance records to estimate heritabilities and correlations for fertility traits (De Haer et al., 2013; Zeleke et al., 2016). The moderate to high positive genetic correlations observed in these studies suggest that improvement of one fertility trait is coupled with an improvement in another. A single fertility trait would not serve well for selection, thus various traits need to be 
combined in an index for optimum genetic progress. More research is required to increase the availability of such information and to fill knowledge gaps, especially in South Africa.

Dairy cattle genetic evaluations have focused on production traits because they are easier to measure and are directly proportional to herd profitability, whereas fitness traits such as reproductive performance are difficult to define and record (Evans et al., 1999; Pryce \& Veerkamp, 2001; Miglior et al., 2005). Consequently, effective selection tools for genetic improvement of reproductive traits were limited (Gutiérrez et al., 2002). Milk yield has doubled in the past 40 years (Oltenacu \& Broom, 2010). In the United States, the average milk production per cow over the period $1957-2007$ increased by $5,9 \mathrm{~kg}$, with $3,4 \mathrm{~kg}$ of this increase (or 56\%) because of genetics (Van Raden, 2004). In South Africa, the Ayrshire breed has made remarkable genetic progress in production traits. Genetic increase of milk production per lactation has been recorded at $44.3 \mathrm{~kg}$ per year since 1983, butterfat production at $1.7 \mathrm{~kg} / \mathrm{year}$, and protein production at 1.4 $\mathrm{kg} /$ year (Mostert et al., 2013). Even though proper management, good nutrition and environmental conditions contributed to the increased milk yields, genetics played a huge role because animals went through intensive genetic selection through the use of artificial insemination (Al) and worldwide distribution of semen from elite progeny-tested bulls (Oltenacu \& Broom, 2010).

With increasing milk production, reproductive performance has been declining (Roxstroem et al., 2001; Royal et al., 2002; Pryce et al., 2004; Oltenacu \& Broom, 2010). Several studies on the genetic relationships between fertility and production traits found that correlations between milk yield and fertility traits were antagonistic and statistically significant (Grosshans et al., 1997; Roxstroem et al., 2001; Strucken et al., 2012; Tenghe et al., 2015). High positive genetic correlations between 305-day milk yield (MY) and Cl showed that an increase in milk yield consequently prolonged $\mathrm{Cl}$ (Table 4).

Table 4 Genetic correlations between 305-day milk yield and calving interval in various dairy breeds

\begin{tabular}{lccl}
\hline Breed & $\begin{array}{c}\text { Genetic } \\
\text { correlation }\end{array}$ & Country & References \\
\hline Holstein-Friesian & 0.58 & Australia & Haile-Mariam et al., 2003 \\
Holstein & 0.69 & South Africa & Makgahlela., et al., 2007 \\
Simmental & 0.35 & Turkey & Ulutas et al., 2009 \\
Holstein & 0.59 & Brazil & Toghiani, 2012 \\
Brown Swiss & 0.68 & Turkey & Sahin et al., 2014 \\
Xinjiang Brown Cattle & 0.47 & China & Fu et al., 2017 \\
Girolando & 0.59 & Brazil & Canaza-Cayo et al., 2017 \\
\hline
\end{tabular}

In a sample of UK dairy cows that were monitored from 1975 to $1982(n=2503)$ and 1995 to $1998(n$ $=704$ ), calving rates to first service declined from $55.6 \%$ to $39.7 \%$ (Royal et al., 2000). There is also evidence of an unfavourable relationship between milk production and oestrus behaviour with shorter oestrus periods (5.5 vs 11.1 hours) in high-producing cows ( $>40 \mathrm{~kg}$ per day) relative to low ( $<30 \mathrm{~kg}$ per day) (Lopez et al., 2004). A study conducted in Poland showed that increased milk yield of first lactation cows (from $\leq 5000 \mathrm{~kg}$ to $>8000 \mathrm{~kg}$ ) had a negative effect on their fertility in the first reproductive cycle, the $\mathrm{Cl}$ calving increased from 378 to 517 days, the service period lengthened from 24 to 130 days, and the insemination interval increased from 1.63 to 3.44 (Sawa \& Bogucki, 2011). In the USA, Lucy (2001) reported an increase in the number of Als required for conception from 1.75 to more than 3 over 20 years. In South Africa, Makgahlela (2008) reported that the $\mathrm{Cl}$ of Holstein cows increased from 386 in 1984 to 420 days in 2004. Increasing the interval between two calving dates reduces the number of calves born per herd/year. Reklewski et al. (2003) pointed out that the negative effect of high milk production on fertility may be because daily lactation yield peaks during the period that cows are more likely to conceive, that is, between 60 and 90 days of calving. The primary reason for reproductive disturbance is the aggravation of the negative energy balance, which leads to intense mobilisation of body fat reserves, thus increasing the incidence of metabolic and hormonal disorders and lengthening the period between calving and first oestrus after calving (Reklewski et al., 2003).

Success or failure of dairy farming depends to a greater extent on the farmer's or breeder's management skills and practices, together with market factors, environmental factors, and the herd genetic composition. Overall, dairy herd health and nutrition are primary determinants of fertility. The feeding level of 
young animals affects the age at which they reach puberty, whereas in mature animals inadequate nutrition reduces the production of ova, which can result in failure to conceive (Shortle, 2014). A negative energy balance normally occurs during early lactation because feed intake is low, whereas milk production is greater as the cows are transitioning. These cause the animal to use body reserves to overcome the energy deficit (Ibtisham et al., 2018). Formulating diets to meet the requirements of the cow while avoiding overconsumption of energy may improve the outcomes of the transition period and lead to improved fertility (Cardoso, 2017).

Body condition score (BCS) is a good herd management tool with which to check the body reserves and energy status of cattle. Because good health, milk production, fertility and fitness depend on a good BCS, it should not be less than 2 to 2.5 and should be the same at drying off and at calving (Garnsworthy, 2007). Body condition score has a direct effect on the fertility of dairy cattle. Carvalho et al. (2014) showed that cows that maintained BCS from calving to 21 days after calving had higher pregnancy per $\mathrm{Al}$ at 40 days $(83.5 \%)$ than those that lost BCS (25.1\%) in the same period. Klopčič et al. (2011) noted that animals that stay in good condition during the first part of lactation show shorter calving intervals. Kadarmideen (2004) showed that BCS has favourable genetic correlations with fertility traits $(-0.35$ with days to first service) and that the genetic merit for BCS increases the genetic merit for lactation somatic cell score (SCS). Through selection of BCS and SCS, an opportunity for indirect selection of resistance to mastitis is provided, because SCS in milk has a genetic correlation of about $70 \%$ with clinical mastitis (Kadarmideen \& Pryce, 2001). Body condition score is detrimental to post-partum health (Markusfeld et al., 1997), in which cows in poor condition at drying off were at greater risk of having retained placentas, and cows that lost more body condition during the dry period suffered more from retained placenta and metritis. A well-balanced ration is recommended throughout the stages of a producing dairy cow to avoid the negative effects caused by poor nutrition.

Successful reproduction is the result of a chain of events, including resumption of oestrous cycles post-partum, the development and ovulation of a healthy oocyte, fertilisation, embryo development, implantation in the uterus, maintenance of pregnancy and parturition (Garnsworthy et al., 2008).

The main behavioural sign of an oestrous period is standing to be mounted, which is used to determine the correct time to inseminate. However, this traditional way of detecting cows is unsatisfactory (Van Eerdenburg et al., 1996). Moreover, in high-yielding herds, the percentage of cows that display standing to be mounted by other cows has decreased. A study by Roelofs et al. (2005b) showed that only $58 \%$ of cows were observed in standing oestrus, leaving it more difficult to detect oestrus. As a result, submission rate to Al would decrease and lead to reduced reproductive efficiency (Crowe et al., 2018). However, the use of a combination of signs of oestrus and heat detection aids has a positive association with reproductive efficiency (Cowen et al., 1998; Rao et al., 2013). Other methods of detection and quantifying oestrus have been recommended, such as pedometers (Roelofs et al., 2005a) and electronic activity tags (Lovendahl \& Chagunda, 2010).

A healthy dairy cow should release its first dominant follicle at around 15 days post-partum, although it may not show typical heat behavioural signs during first ovulation. This 'silent oestrus' is thought to be the result of high oestradiol (E2) concentrations of foetal origin at the end of gestation, which induces 'refractoriness' in the hypothalamus to E2 at the first postpartum ovulation (Boer et al., 2010). However, behavioural signs will be present at the subsequent oestrus owing to the effect of the corpus luteum produced after the first ovulation, which provides the progesterone $\left(\mathrm{P}_{4}\right)$ that removes the refractory state.

The percentage of cows that become pregnant from first postpartum insemination has declined from $55.6 \%$ to $39.7 \%$, which was attributed to an increase in the proportion of cows exhibiting atypical ovarian hormone patterns from $32 \%$ to $44 \%$ (Royal et al., 2000). Atypical ovarian hormone patterns, such as extended anoestrus or prolonged high progesterone concentrations often require pharmacological interventions before normal cycles can be resumed (Pring et al., 2012). The delay of normal patterns of early resumption of ovulation in high-yielding Holstein-type cows may be owing to the effects of severe negative energy balance, dystocia, retained placental membranes and uterine infections (Crowe et al., 2014). The key to optimising the resumption of ovulation in dairy cows is appropriate pre-calving nutrition and management so that the cows calve down in optimal body condition (BCS of 2.75 to 3.0) with postpartum body condition loss restricted to 0.5 BCS units (Crowe et al., 2014). This would ensure that cows would become inseminated shortly after calving and conceive earlier, resulting in shorter calving intervals.

Advancements in genotyping by sequencing technologies have facilitated the identification of single nucleotide polymorphisms (SNPs), which provide additional data for use in genetic evaluations of animals. Genomic selection identifies genetically superior selection candidates based on breeding values predicted as the sum of allele substitution effects of thousands of genome-wide SNP markers from the reference populations with phenotypes and genotypes (Meuwissen et al., 2001; Goddard, 2009). This allows early selection of young animals without phenotypic information, and reduces the generation interval, thus accelerating the rate of genetic improvement. High genetic gains can be achieved through using young 
animals without performance records as parents for the next generation (De Roos et al., 2011; Buch et al., 2012). Several statistical models have been developed for genomic evaluations, categorised mainly into best linear unbiased prediction (BLUP) approaches, which assume normally distributed SNP effects with equal variance, and Bayesian algorithms, which assume unequal variance of SNP effects (Meuwissen et al., 2001; Van Raden, 2008). In multi-step genomic best linear unbiased prediction (GBLUP), the SNP effects are estimated and summed to obtain direct genomic values or are used to build a genomic relationship matrix that simply replaces the pedigree-derived numerator relationship matrix (Habier et al., 2007, Van Raden, 2008). Using the selection index approach, the estimated direct genomic values would subsequently be blended with EBV, weighted by their reliabilities to obtain genomic breeding values (GEBV). The purpose of blending is to recover ancestral information from the EBV (Van Raden et al., 2009). In the single-step GBLUP or unified approach, the pedigree and genomic information are combined into a single relationship matrix, which then enters the mixed-model equations to obtain GEBV for both genotyped and ungenotyped animals (Misztal et al., 2009; Christensen \& Lund, 2010). Genomic selection will be especially important for low heritable complex traits that have been difficult and expensive to measure such as fertility, disease and meat quality. The reliabilities of GEBV were found to be considerably greater than those of conventional parent averages (PA). For example, VanRaden et al. (2009) reported an expected genomic reliability of $63 \%$ for 26 traits, which was double the reliability of $27 \%$ for PA. Su et al. (2010) reported reliability of $55 \%$ averaged over 18 traits, which was close to double the reliability of $29 \%$ achieved for PA. A genomic breeding scheme was shown to be superior to a conventional breeding scheme, even in small dairy cattle populations (Thomasen et al., 2014).

The cost of genotyping is a limiting factor in the adoption of genomic selection in developing countries such as South Africa. However, the cost of genotyping can be countered by greater saving costs because of the elimination of PT and additional annual monetary genetic gain owing to the reduction of generation intervals in genomic breeding programmes (GBP). This was shown in the study by König et al. (2009), in which a distinct economic advantage in discounted profit was found for all scenarios of GBP in the range of factor 1.36 to 2.59. The cost effectiveness of genomic selection compared with progeny testing was supported by Kariuki et al. (2017) in their gross margins study for PT and genomic selection (GS) schemes. This highlights that the GS breeding scheme is economically viable for developing countries because the higher the margin, the more effective company management in generating revenue for each unit of cost. Shortening the generation interval can also be achieved through the combined use of marker assisted selection and germ-line manipulations, known as velogenetics, which allows efficient introgression of mapped economic trait loci between genetic backgrounds (Georges \& Massey, 1991). Through the process of velogenetics, Holstein calves have already been born from oocytes aspirated from eight-month-old females that were fertilised in vitro by the sperm of 10-month-old bulls (Taylor, 2016). Imputation algorithms can be applied to derive high-density genotypes from low-density genotypes, thereby increasing the size of the reference population (Calus et al., 2014). The loss in accuracy of GEBV estimated from imputed genotypes is reported to be between $0 \%$ and $45 \%$ (Habier et al., 2009; Weigel et al., 2010). Imputation could be used to deduce missing genotypes and would be helpful in increasing the large reference populations that are needed for accurate genomic selection (Weng et al., 2012). The low cost of genotyping would result in a large number of candidates being screened, hence increasing selection intensity. The shift towards genomic selection could be economically feasible for South Africa in improving low heritable traits such as fertility. However, genomic selection is not a 'silver bullet'. The need to have appropriate measures for female fertility remains the cornerstone of the much articulated gains in genomic selection.

\section{Conclusion}

The declining trend in fertility is being reversed by its inclusion in multi-trait selection indices, together with production and other functional traits. Fertility traits have been reported to have reasonable additive genetic variation, which shows that improvements are possible through genetic selection, despite low heritability estimates for individual traits. Several countries have already constructed multi-trait selection indices to select for all traits of economic importance, including fertility. Genomic selection is a promising opportunity for accelerating genetic improvement of complex traits such as fertility. Several countries have implemented genomic selection and demonstrated its potential in accelerating the rate of genetic improvement and the cost benefits. Successful implementation of additional fertility traits in genetic improvement programmes of South African dairy cattle would be dependent on whole-herd reporting and on cattle breeders optimising the use of technologies to improve the current state of female fertility.

\section{Acknowledgements}

The authors would like to acknowledge National Research Foundation, Dairy Genomics Project and Technology Innovation Agency as an implementing agency for the Department of Science and Innovation for financial support. 


\section{Authors' Contributions}

the manuscript.

RDK designed and drafted the manuscript, MLM drafted the manuscript, and CJCM and KD critically evaluated

\section{Conflict of Interest Declaration}

Authors declare that they have no conflicts of interest.

\section{References}

Amimo, J.O., Mosi, R.O., Wakhungu, J.W., Muasya, T.K. \& Inyangala, B.O., 2006. Phenotypic and genetic parameters of reproductive traits for Ayrshire cattle on large-scale farms in Kenya. Livest. Res. Rural Dev. 18, 10.

Anonymous., 2017. The flow of animals in a dairy herd. In: Dairy farming handbook. Western Cape Department of Agriculture, Elsenburg, South Africa. P. 179.

Banga, C.B., Neser, F.W.C., Van der Westhuizen, J. \& Garrick, D.J., 2009. Economic values for dairy production traits under different milk payment systems in South Africa. S. A. J. Anim. Sci. 39, 112-115.

Berry, D.P., Kearney, J.F., Twomey, K. \& Evans, R.D., 2013. Genetics of reproductive performance in seasonal calving dairy cattle production systems. Irish J. Agric. Food Res. 52, 1-16.

Biffani, S., Canavesi, R. \& Samore, A.B., 2003. Estimates of genetic parameters for fertility traits of Italian HolsteinFriesian cattle. Stocarstvo. 59,145-153.

Boer, H.M.T., Veerkamp, R.F. \& Beerda, B.W., 2010. Estrous behavior in dairy cows: Identification of underlying mechanisms and gene functions. Animal 4, 446-453.

Buch, L.H., Sorensen, M.K., Berg, P., Pedersen, L.D. \& Sorensen, A.C., 2012. Genomic selection strategies in dairy cattle: Strong positive interaction between use of genotypic information and intensive use of young bulls on genetic gain. J. Anim. Breed. Genet. 129, 138-151.

Calus, M., Bouwman, A., Hickey, J., Veerkamp, R. \& Mulder, H., 2014. Evaluation of measures of correctness of genotype imputation in the context of genomic prediction: A review of livestock applications. Animal 8,11, 17431753. DOI: $10.1017 / \mathrm{S} 1751731114001803$

Cardoso, F., 2017. Pre- and postpartum nutritional management to optimize energy balance end fertility in dairy cows. Proc. 28th Annual Florida Rum. Nutr. Symp., 6-8 February 2017.

Carvalho, P.D., Souza, A.H., Amundson, M.C., Hackbart, K.S., Fuenzalida, M.J., Herlihy, M.M., Ayres, H., Dresch, A.R., Vieira, L.M., Guenther, J.N., Grummer, R.R., Fricke, P.M., Shaver, R.D. \& Wiltbank, M.C., 2014. Relationships between fertility and postpartum changes in body condition and body weight in lactating dairy cows. J. Dairy Sci. 97, 3666-3683.

Cassandro, M., 2014. Genetic aspects of fertility traits in dairy cattle - Review. Acta Agraria Kaposváriensis, 18, 11-23.

Canaza-Cayo, A.W., Lopes, S.P., Cobucic, J.A., Martins, M.F. \& Barbosa da Silva, M.V.G., 2017. Genetic parameters of milk production and reproduction traits of Girolando cattle in Brazil. Italian J. Anim. Sci. 17, 22-30.

Cervo, H.J., Barcellos, J.O.J, Peripolli, V., Colle, G. \& McManus, C., 2017. Economic values for production, functional and fertility traits in milk production systems in southern Brazil. Arch. Zootech. 66, 419-27.

Christensen, O.F. \& Lund, M.S., 2010. Genomic prediction when some animals are not genotyped. Genet. Sel. Evol. 42 , 2. https://doi.org/10.1186/1297-9686-42-2

Colleau, J. \& Moureaux, S., 1999. Constructing the selection objective of the French Holstein population. Interbull Bull. 23, 41-46.

Cowen, P., Schwabe, C.W., Rosenberg, H.R., Bondurant, R.H., Franti, C.E. \& Goodger, W.J., 1998. Reproductive management practices among Tulare, California, dairy herds. Census and descriptive aspects. Prey. Vet. Med. 7, 83-100.

Crowe, M.A., Diskin, M.G. \& Williams, E.J., 2014. Parturition to resumption of ovarian cyclicity: Comparative aspects of beef and dairy cows. Animal 8, 40-53

Crowe, M.A., Hostens, M. \& Opsomer, G., 2018. Reproductive management in dairy cows - The future. Ir. Vet. J. 71, 113.

Darwash, A.O., Lamming, G.E. \& Woolliams, J.A., 1997. Estimation of genetic variation in the interval from calving to postpartum ovulation of dairy cows. J. Dairy Sci. 80, 1227-1234.

De Haer, L.C.M., De Jong, G. \& Vessies, P.J.A., 2013. Estimate of genetic parameters of fertility traits, for virgin heifers in the Netherlands. Interbull Bull. 47, 143-146.

De Jong, G., 1998. Index for daughters' fertility in the Netherlands. Interbull Bull. 18, 102-105.

De Roos, A.P.W., Schrooten, C., Veerkamp, R.F. \& van Arendonk, J.A.M., 2011. Effects of genomic selection on genetic improvement in breeding, and merit of young versus proven bulls. J. Dairy Sci. 94, 1559-1567.

Dillon, P., Berry, D.P., Evans, R.D., Buckley, F. \& Horan, B., 2006. Consequences of genetic selection for increased milk production in European seasonal pasture based systems of milk production. Livest. Sci. 99, 141-158.

Du Plessis, M. \& Roux, C.Z., 1998. Economic weights for Holstein Friesian traits in South Africa. S. Afr. J. Anim. Sci. 28, 140-145

Eghbalsaied, S., 2011. Estimation of genetic parameters for 13 female fertility indices in Holstein dairy cows. Trop. Anim. Health Prod. 43, 811-816.

Esslemont R.J., 1992. Measuring dairy herd fertility. Vet. Rec. 131, 209-212.

Evans, J.L., Golden, B.L., Bourdon, R.M. \& Long, K.L., 1999. Additive genetic relationships between heifer pregnancy and scrotal circumference in Hereford cattle. J. Anim. Sci. 77, 2621-2628. 
Fu, X.F., Lu, L.L., Huang, X.X., Wang, Y.C., Tian, K.C., Xu, X.M., Fang, J.Q., Cheng, L.M., Guo, Z.Q. \& Tian, Y.Z., 2017. Estimation of genetic parameters for 305 day milk yields and calving Interval in Xinjiang Brown Cattle. Agricultural Sci. 8, 46-55.

Garnsworthy, P., 2007. Body condition score in dairy cows: Targets for production and fertility. Recent Advances in Animal Nutrition 61-86. DOI: 10.5661/recadv-06-61.

Garnsworthy, P.C., Sinclair, K.D. \& Webb, R., 2008. Integration of physiological mechanisms that influence fertility in dairy cows. Animal 2, 1144-1152. DOI: 10.1017/S1751731108002358.

Georges, M. \& J.M. Massey, 1991 Velogenetics, or the synergistic of marker assisted selection and germ-line manipulation. Theriogenology 35, 151-159.

Ghaderi-Zefrehei, M., Rabbanikhah, E., Bahneh, H., Peters, S.O. \& Imumorin, I.G., 2017. Analysis of culling records and estimation of genetic parameters for longevity and some production traits in Holstein dairy cattle. Journal of Applied Animal Research 45, 1,524-5

Glaze, J.B., 2011. Genetic selection for fertility and performance. Proceedings: Applied Reproductive Strategies in Beef Cattle. Pp. 255- 262.

González-Recio, O. \& Alenda, R., 2005 Genetic parameters for female fertility traits and a fertility index in Spanish dairy cattle J. Dairy Sci. 88, 3282-3289.

Grosshans T., Xu Z.Z., Burton L.J., Johnson D.L. \& Macmillan K.L., 1997. Performance and genetic parameters for fertility of seasonal dairy cows in New Zealand. Livest. Prod. Sci. 51, 290-297.

Guo, G., Guo, X., Wang, Y., Zhang, X., Zhang, S., Li, X., Liu, L., Shi, W., Usman, T., Wang, X., Du, L. \& Zhang, Q., 2014. Estimation of genetic parameters of fertility traits in Chinese Holstein cattle. Can. J. Anim. Sci. 94, 281-285.

Gutiérrez, J.P., Alvarez, I., Fernandez, I., Royo, L.J., Díez, J. \& Goyache, F., 2002. Genetic relationships between calving dates, calving interval, age at first calving and type traits in beef cattle. Livest. Prod. Sci. 78, 215.

Habier D., Fernando R.L. \& Dekkers J.C.M., 2007. The impact of genetic relationship information on genome-assisted breeding values. Genetics 177, 2389-2397

Habier, D., Fernando, R.L. \& Dekkers, J.C.M., 2009. Genomic selection using low-density marker panels. Genetics 182 , 343-353.

Haile-Mariam, M., Bowman P.J. \& Goddard, M.E., 2003. Genetic and environmental relationships among calving interval, survival, persistency of milk yield and somatic cell count in dairy cattle. Anim. Sci. 80, 189-200.

Holmes, C.W., Brookes, I.M., Garrick, D.J., Mackenzie, D.D.S., Parkinson, T.J. \& Wilson, G.F., 2000. Milk production from pasture. Massey University, Palmerston North, New Zealand.

Ibtisham, F., Nawab, A., Li., Xiao, M., An, L. \& Naseer, G., 2018. Effect of nutrition on reproductive efficiency of dairy animals. Medycyna Weterynaryjna 74. 6025-2018. DOI, 10.21521/mw.6025.

Inchaisri, C., Jorritsma, R., Vos, P.L.A.M., Van der Weijden, G.C. \& Hogeveen, H., 2010. Economic consequences of reproductive performance in dairy cattle. Theriogenology 74, 835-46.

Kadarmideen, H.N., 2004. Genetic correlations among body condition score, somatic cell score, milk production, fertility and conformation traits in dairy cows. J. Anim. Sci. 79, 191-201.

Kadarmideen, H. \& Pryce, J., 2001. Genetic and economic relationships between somatic cell count and mastitis and their use in selection for mastitis resistance in dairy cattle. J. Anim. Sci. 73.19-28. DOI: 10.1017/S135772980005801X

Kariuki, C.M., Brascamp, E.W., Komen, H., Kahi, A.K. \& Van Arendonk J.A., 2017. Economic evaluation of progenytesting and genomic selection schemes for small-sized nucleus dairy cattle breeding programs in developing countries J. Dairy Sci. 100, 2258-2268.

Kgari, R.D., Muller, C.J.C. \& Makgahlela, M.L. 2019. Reproductive traits for more efficient genomic selection. The Dairy Mail 7, 80-85.

Klopčič, M., Hamoen, A. \& Bewley, J., 2011. Body condition scoring of dairy cows. Republika Slovenija Ministrstvo Za Kmetijstvo, Gozdarstvo in Prehrano. http:/www.holstein.si/PDF/body\%20condition\%20of\%20dairy\%20cows.pdf

König, S., Simianer, H. \& Willam, A., 2009. Economic evaluation of genomic breeding programs. Dairy Sci. 92,382-391.

Lavern, R., 2017. Fertility in dairy herds - Advanced Part 1: What does poor fertility cost? https://www.nadis.org.uk/disease-a-z/cattle/fertility-in-dairy-herds-advanced/part-1-what-does-poor-fertility-cost/

Leitch, H., 1994. Comparison of international selection indices for dairy cattle breeding. Interbull Bull. No. 10.

Liu, A., Lund, M.S., Wang, Y., Guo, G., Dong, G., Madsen, P. \& Su, G. 2017. Variance components and correlations of female fertility traits in Chinese Holstein population. J. Anim. Sci. Biotechnol. 8. DOI: 10.1186/s40104-017-0189-x

Lopez, H., Satter, L.D. \& Wiltbank, M.C., 2004. Relationship between level of milk production and oestrous behavior of lactating dairy cows. Animal Reproduction Science 81, 209-223.

Lovendahl, P. \& Chagunda, M.G., 2010. On the use of physical activity monitoring for estrus detection in dairy cows. J. Dairy Sci. 93, 249-259.

Lucy, M.C., 2001. Reproductive loss in high-producing dairy cattle: Where will it end? J Dairy Sci. 84, 1277-1293.

Makgahlela, L., 2008. Calving interval now included in the national genetic evaluation. National Milk Recording and Improvement Scheme. Newsletter 13, 20.

Makgahlela, M.L., Banga, C.B., Norris, D., Dzama, K. \& Ng'ambi J.W., 2007. Genetic correlations between female fertility and production traits in South African Holstein cattle. S. A. J. Anim. Sci. 37 (3), 180-188.

Markusfeld, O., Galon, N. \& Ezra, E., 1997. Body condition score health, yield and fertility in dairy cows. Veterinary Record 141, 67-72.

Meuwissen, T.H.E., Hayes, B.J. \& Goddard, M.E., 2001. Prediction of total genetic value using genome-wide dense marker maps. Genetics 157, 1819-1829. 
Meyer, C. \& Zwald N., 2014. What you need to know about selection indexes. https://www.progressivedairy.com/topics/a-i-breeding/what-you-need-to-know-about-selection-indexes

Miglior, F., 1999. Selection for fertility traits Proc. 24th Environmental Health Foundation of Canada (EHFC) Meeting, Auburn, Ontario, 1999.

Miglior, F., Muir, B.L. \& Van Doormaal, B.J., 2005. Selection indices in Holstein cattle of various countries. J. Dairy Sci. $88,1255-1263$

Misztal, I., Legarra, A. \& Aguilar, I., 2009. Computing procedures for genetic evaluation including phenotypic, full pedigree and genomic information. J. Dairy Sci. 92, 4648-4655.

Mostert, B.E., Van der Westhuizen, R.R. \& Theron, H.E., 2010. Calving interval genetic parameters and trends for dairy breeds in South Africa. S. Afr. J. Anim. Sci. 40, 156-162.

Mostert, B.E., Van der Westhuizen, R.R. \& Theron, H.E., Van der Westhuizen Steyn, J., 2013. Genetic evaluations for the Ayrshire breed. Logix News 027

Muller, C.J.C., Potgieter J.P, Cloete S.W.P. \& Dzama, K., 2014. Non-genetic factors affecting fertility traits in South African Holstein cows. S. Afr. J. Anim. Sci. 44, 54-63.

Muller, C.J.C., Potgieter, J.P., Zishiri, O. \& Cloete, S.W.P., 2012. Using farmers' records to determine genetic parameters for fertility traits for South African Holstein cows. Proc. 38th International Committee on Animal Recording Session. Session T1. Cork, Ireland.

Norman, H.D., Wright, J.R., Hubbard, S.M., Miller, R.H. \& Hutchison, J.L., 2009. Reproductive status of Holstein and Jersey cows in the United States, J. Dairy Sci. 92, 3517-3528.

NTM unlocked - What is NTM? 15 September 2017. www.vikinggenetics.com/aboutus/ntm/ntm-unlocked.

Olori, V.E., Meuwissenand, T.H.E. \& Veerkamp, R.F., 2002. Calving interval and survival breeding values as a measure of cow fertility in a pasture-based production system with seasonal calving. J. Dairy Sci. 85, 689-696

Oltenacu, P.A. \& Broom, D.M., 2010. The impact of genetic selection for increased milk yield on the welfare of dairy cows. Animal Welfare 19(S), 39-49.

Overton, M.W., 2009. Using reproductive records: Basics of monitoring. Proceedings 46th Florida Dairy Production Conference, Gainesville, 33-45.

Pedersen, J., Sørensen, M.K., Toivonen, M., Eriksson, J. \& Aamand, G.P., 2008. Report on economic basis for a Nordic total merit index. https://www.journalofdairyscience.org/article/S0022-0302(14)00684-5/abstract

Potgieter, J.P., 2012. Estimation of genetic parameters for fertility traits and the effect of milk production on reproduction performance in South African Holstein cows. MSc (Agric) thesis, University of Stellenbosch, South Africa.

Potgieter, J.P., Muller, C.J.C., Cloete, C.W.P., Zishiri, O.T. \& Dzama, K., 2011. Exploring fertility traits other than calving interval for inclusion in a national genetic evaluation for South African Holstein cows. Proc. Assoc. Advmt. Anim. Breed. Genet. 19, 482-485.

Pring, S., Owen, M., King, J., Sinclair, K., Webb, R., Flint, A. \& Garnsworthy, P., 2012. A mathematical model of the bovine oestrous cycle: Simulating outcomes of dietary and pharmacological interventions. J. Theor. Biol. 313, $115-126$

Pryce, J.E. \& Veerkamp, R.F., 2001. The incorporation of fertility indices in genetic improvement programmes. BSAS Occasional Publication 26, 237-250.

Pryce, J.E., Royal, M.D., Garnsworthy, P.C. \& Mao, I.L., 2004. Fertility in the high-producing dairy cow. Livest. Prod. Sci. 86,125-135.

Rahbar, R., Aminafshar, M., Abdullahpour, R. \& Chamani, M., 2016. Genetic analysis of fertility traits of Holstein dairy cattle in warm and temperate climate. Acta Sci., Anim. Sci. 38 (3), 333-340.

Rao, T.K.S., Kumar, N., Kumar, P., Chaurasia, S. \& Patel, N.B., 2013. Heat detection techniques in cattle and buffalo. Vet. World 6, 363-369.

Reklewski, Z., Dymnicki, E., Oprządek, J., Oprządek, A. \& Krzyżewski, J., 2003. Relationship between calving interval and insemination coefficient and milk capacity of cows in 305-days lactation. Ann of Warsaw. Agricult Univ SGGW 39, 58-65.

Rensing, S., Pasman, E., Reinhardt, F. \& Feddersen, F., 2002. New total merit index RZG for Holsteins in Germany with more emphasis on herd life. Interbull, Bulletin No. 29, 147-149.

Roelofs, J.B., Van Eerdenburg, F.J.C.M., Soede, N.M. \& Kemp, B., 2005a. Pedometer readings for estrous detection and as predictor for time of ovulation in dairy cattle. Theriogenology 64, 1690-1703.

Roelofs, J.B., Van Eerdenburg, F.J.C.M., Soede, N.M. \& Kemp, B., 2005b. Various behavioral signs of estrous and their relationship with time of ovulation in dairy cattle. Theriogenology 63, 1366-77.

Royal, M.D., Flint, A.P.F. \& Woolliams, J.A., 2002. Genetic and phenotypic relationships among endocrine and traditional fertility traits and production traits in Holstein-Friesian dairy cows. J. Dairy Sci. 85, 958-967.

Royal, M.D., Darwash, A.O., Flint, A.P.F., Webb, R., Woolliams, J.A. \& Lamming, G.E., 2000. Declining fertility in dairy cattle: Changes in traditional and endocrine parameters of fertility. Anim. Sci. 70, 487- 501.

Roxstroem, A., Strandberg, E., Berglund, B., Emanuelson, U. \& Philipsson, J., 2001. Genetic and environmental correlations among female fertility traits and milk production in different parities of Swedish Red and White dairy cattle. Acta Agric. Scand. 51, 7-14.

Sahin, A., Ulutas, Z., Adkinson, A.Y. \& Adkinson, R.W., 2014. Genetic parameters of first 80 Salem and Hammoud lactation milk yield and fertility traits in Brown Swiss cattle. Annals Anim. Sci. 14, 545.

Sawa, A. \& Bogucki, M., 2011. Effect of housing system and milk yield on cow fertility. Arch. Tierz. 54, $249-256$.

Seegers, H., 2006. Economics of the reproductive performance of dairy herds. Proc. World Buiatrics Congr. $292-302$.

Senger, P.L., 2001. Review: Fertility factors in high producing dairy cows - which ones are really important? Prof. Anim. Scientist 17, 129-138. 
Shook, G. E., 2006. Major advances in determining appropriate selection goals. J. Dairy Sci. 89,1349-1361.

Shortle, W., 2014. Fertility in dairy cattle: A review. http://www.huveta.hu/bitstream/handle/10832/1253/WilliamShortle.pdf?sequence=1\&isAllowed=y

Strucken, E.M., Borgfeldt, R.H. \& Tetens J., 2012. Genetic effects and correlations between production and fertility traits and their dependency on the lactation-stage in Holstein Friesians. BMC Genetics 13, 108.

Su, G., Guldbrandtsen, B., Gregersen, V.R. \& Lund, M.S., 2010. Preliminary investigation on reliability of genomic estimated breeding values in the Danish Holstein population J. Dairy Sci., 93, 1175-1183.

Taylor, J.F., Taylor, K.H. \& Decker, J.E., 2016. Holsteins are the genomic selection poster cows. Proc. Natl. Acad. Sci., USA, 113, 7690-7692. DOI: 10.1073/pnas.1608144113

Tenghe, A.M.M., Bouwman, A.C., Berglund, B., Strandberg, E., Blom, J.Y. \& Veerkamp, R.F., 2015. Estimating genetic parameters for fertility in dairy cows from in-line milk progesterone profiles. J. Dairy Sci. 98, 5763-73.

Theron, H. \& Mostert, B., 2019. Livestock breeding and animal welfare. Logix News 4, 8-9.

Tiezzi, F., Maltecca, C., Cecchinato, A., Penasa, M. \&. Bittante, G., 2012. Genetic parameters for fertility of dairy heifers and cows at different parities and relationships with production traits in first lactation J. Dairy Sci. 95, 7355-7362.

Thomasen, J.R., Willam, A., Guldbrandtsen, B., Lund, M.S. \& Sørensen, A.C., 2014. Genomic selection strategies in a small dairy cattle population evaluated for genetic gain and profit. J. Dairy Sci. 97, 458-470.

Toghiani, S., 2012. Genetic relationships between production traits and reproductive performance in Holstein dairy cows. Arch. Tierz. 55, 458-468.

Ulutas, S. \& Sezer, M., 2009. Genetic Study of milk production and reproduction traits of local born Simmental cattle in Turkey. GOÜ. Ziraat Fakültesi Dergisi 26, 53-59.

Van Arendonk, J.A.M., Hovenier, R. \& De Boer, W., 1989. Phenotypic and genetic association between fertility and production in dairy cows. Livest. Prod. Sci. 21,1-12.

Van Raden P., 2008. Efficient methods to compute genomic predictions. J. Dairy Sci. 91, 4414-4423.

Van Raden, P.M., 2004 Invited review: Selection on net merit to improve lifetime profit. J. Dairy Sci. 87, 3125-3131.

Van Raden P., 2008. Efficient methods to compute genomic predictions. J. Dairy Sci. 91, 4414-4423.

Van Raden P.M., Van Tassell C.P., Wiggans G.R., Sonstegard, T.S., Schnabel, R.D., Taylor, J.F. \& Schenkel§, F.S., 2009. Invited review: Reliability of genomic predictions for North American Holstein bulls. J. Dairy Sci. 92, 16-24.

Van Marle-Köster, E. \& Visser, C., 2018. Genetic improvement in South African livestock: Can genomics bridge the gap between the developed and developing sectors? Front. Genet. 9, 1-12.

Van Eerdenburg, F.J.C.M., Loeffler, H.S.H. \& Van Vliet, J.H., 1996. Detection of estrus in dairy cows: A new approach to an old problem. Veterinary Quarterly 18, 52-54.

Veerkamp, R.F., Dillon, P., Kelly, E., Cromie, A.R. \& Groen, A.F., 2002. Dairy cattle breeding objectives combining yield, survival and calving interval for pasture-based systems in Ireland under different milk quota scenarios. Livest. Prod. Sci. 76, 137-151.

Visscher, P.M., Bowman, P.J. \& Goddard, M.E., 1994. Breeding objectives for pasture-based dairy production systems. Livest. Prod. Sci. 40, 123-137.

Viana, J.M.S., Piepho, H. \& Silva, F.F., 2016. Quantitative genetics theory for genomic selection and efficiency of breeding value prediction in open-pollinated populations. Scientia Agricola 73, 243-251.

Walsh, S.W., Williams, E.J. \& Evans, A.C.O., 2011. A review of the causes of poor fertility in high milk producing dairy cows. Anim. Reprod. Sci. 123, 127-138.

Weigel, K.A. \& Rekaya, R., 2000., Genetic parameters for reproductive traits of Holstein cattle in California and Minnesota, J. Dairy Sci. 83, 1072-1080.

Weigel, K., de los Campos, G., Vazquez, A., Rosa, C.V.T.G., Gianola, D., O’Connell, J., VanRaden, P. \& Wiggans, G., 2010. Genomic selection and its effects on dairy cattle breeding programs. Abstract 0119 in Proc. 9th World Congr. Genet. Appl. Livest. Prod., Leipzig, Germany.

Weng, Z., Zhang, Z., Ding, X., Fu, W., Ma, P. \& Wang, C., 2012. Application of imputation methods to genomic selection in Chinese Holstein cattle. J. Anim. Sci. Biotechno. 3, 6.

Wesseldijk, B., 2004. Secondary traits make up $26 \%$ of breeding goal. Holstein Inter. 11, 8-11.

Yin, T. \& König, S., 2018. Genetic parameters for body weight from birth to calving and associations between weights with test-day, health, and female fertility traits. J. Dairy Sci. 101, 2158-2170.

Zaabza, H.B., Gara, A.B., Hammami, H., Jemmali, B., Ferchichi, M.A. \& Rekik, B., 2016. Genetic parameters of reproductive traits in Tunisian Holsteins. Arch. Anim. Breed. 59, 209-213.

Zeleke, B, Kebede, K. \& Banerjee A.K., 2016. Estimation of genetic parameters for reproductive traits of Fogera and Holstein Friesian crossbred cattle at Metekel Ranch, Amhara Region, Ethiopia. Online J. Anim. Feed Res. 6, 9095.

Zink, V., Lassen, J. \& Stipkova, M., 2012. Genetic parameters for female fertility and milk production traits in first-parity Czech Holstein cows. Czech J. Anim. Sci. 5, 108-114. 